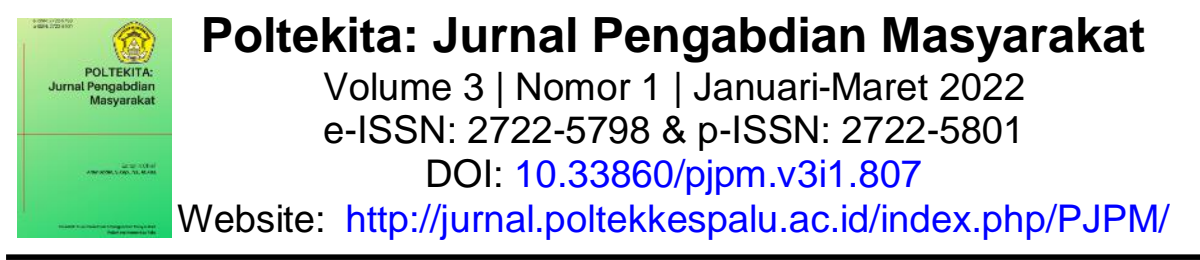

\title{
Pelatihan Keterampilan Konseling Gizi pada Kader Posyandu di Wilayah Kerja Puskesmas Panambungan, Makassar
}

\author{
Nurbaya $\square\left[D^{1}\right.$, Icha Dian Nurcahyani ${ }^{(D 2}{ }^{2}$, Mohammad Khomeiny $\mathbb{D}^{3}$, Wahyu Chandra $\mathbb{D}^{4}$ \\ ${ }^{1} J u r u s a n$ Gizi, Poltekkes Kemenkes Mamuju, Mamuju, Indonesia \\ ${ }^{2}$ Stikes Salewangan Maros, Maros, Indonesia \\ ${ }^{3}$ Program Pascasarjana Antropologi, FISIP, Universitas Hasanuddin, Makassar, Indonesia \\ ${ }^{4}$ Jalin Institute, Makassar, Indonesia \\ 区mail korespondensi: nurbaya.m.gizi@gmail.com
}

\section{Article history: \\ Received: 19-12-2021 \\ Kata kunci \\ Kader Posyandu; \\ Stunting; \\ Konseling.}

Accepted: 09-01-2022

Published: 13-02-2022

\section{Keywords:}

Posyandu Cadre;

Stunting;

Counselling.

\section{ABSTRAK}

Data Riskesdas tahun 2018 menunjukkan prevalensi balita stunting di Sulawesi Selatan sebanyak 35,7\%. turun hingga 30,59\% pada tahun 2019 berdasarkan data SSGBI. Untuk wilayah Kota Makassar tercatat $8.61 \%$ balita stunting. Berdasarkan data tersebut, pemerintah kota Makassar menetapkan upaya penurunan stunting fokus pada upaya pencegahan stunting sejak dini. Salah satu upaya yang dapat dilakukan adalah melalui pelatihan kader Posyandu sebagai salah satu kelompok yang paling dekat dengan ibu dan balita di Masyarakat. Kegiatan pengabdian masyarakat ini dilakukan oleh Jalin Institute bekerja sama dengan Tim PKK Kota Makassar. Kegiatan ini bertujuan untuk meningkatkan pengetahuan dan keterampilan konseling kader posyandu dalam melakukan konseling gizi di masyarakat. Sebanyak 33 Kader Posyandu terlibat sebagai peserta. Metode yang digunakan adalah pemberian edukasi dalam bentuk ceramah dan diskusi. Pada tahap evaluasi, kader mampu menjawab pertanyaan dan memberikan umpan balik dengan benar. Hal ini mengindikasikan adanya peningkatan pengetahuan setelah pemberian edukasi. Diperlukan komitmen semua pihak dalam upaya pencegahan stunting di Kota Makassar, termasuk dalam bentuk kegiatan pelatihan pada kader Posyandu yang dilakukan secara rutin.

\section{ABSTRACT}

Data from Riskesdas 2018 showed the prevalence of stunting among underfive children in South Sulawesi was $35.7 \%$ and decreased up to $30,59 \%$ in 2019 based on SSGBI. As much as $8.61 \%$ of children under five were stunted in the Makassar City area. Based on this data, the government of Makassar has set stunting reduction efforts to focus on preventing stunting from an early stage. One effort that can be done is through training for Posyandu cadres as one of the groups closest to mothers and children within the community. This community service activity was carried out by the Jalin Institute in collaboration with the PKK Team of Makassar City. This activity aimed to improve the knowledge and counseling skills of Posyandu cadres in conducting breastfeeding and nutrition counseling in the community. As many as 33 Posyandu cadres participated in this activity. The method used is the provision of education in the form of lectures and discussions. At the evaluation stage, cadres can answer questions and provide feedback correctly. It indicated an increase in knowledge after the provision of education. Commitment from all parties is needed in efforts to prevent stunting in Makassar City, including in the form of training activities for Posyandu cadres that are carried out regularly. 


\section{PENDAHULUAN}

Hingga saat ini stunting masih menjadi masalah gizi pada balita bukan hanya di Indonesia, namun menjadi masalah gizi global. Sekitar 52,9 juta balita terhambat perkembangannya karena stunting (World Health Organization \& UNICEF, 2021). Sehingga upaya penurunan angka stunting pada balita bahkan menjadi salah satu target global yang berupaya dicapai pada tahun 2025 (Rana \& Mavalankar, 2021). Secara global, kejadian stunting pada balita telah terjadi penurunan dari 165,8 juta pada tahun 2012 menjadi 149 juta pada tahun 2018. Penurunan yang terjadi sekitar 10\% (The Global Nutrition Report's Independent Expert Group, 2020). Sekitar 90\% dari anak-anak stunting global tinggal di Afrika dan Asia (Tariku, Biks, Derso, Wassie, \& Abebe, 2017). Oleh karena itu, pemerintah menargetkan penurunan prevalensi stunting nasional hingga 14\% pada tahun 2024 (Kementerian Kesehatan R.I. \& BPS, 2019).

Data Riset Kesehatan Dasar (Riskesdas) tahun 2013 menunjukkan 37,2\% atau sekitar 9 juta anak balita mengalami stunting. Pada tahun 2018, prevalensi stunting mengalami penurunan menjadi 30,8\%. Untuk wilayah Sulawesi Selatan terdapat 35,7\% balita stunting (Kementerian Kesehatan R.I., 2013, 2018). Dan pada tahun 2019 menunjukkan terjadi penurunan hingga 30,59\% berdasarkan data SSGBI (Kementerian Kesehatan R.I. \& BPS, 2019). Sementara itu sebanyak $8.61 \%$ balita stunting di kota Makassar. Berdasarkan data tersebut, pemerintah kota Makassar kemudian menetapkan upaya penurunan stunting bukan lagi fokus pada upaya pengobatan, namun fokus pada upaya pencegahan stunting sejak dini (Yunus, Septiyanti, \& Rahman, 2021).

Masalah stunting menjadi masalah bersama secara global karena stunting balita bukan hanya menimbulkan dampak jangka pendek berupa peningkatan morbiditas dan mortalitas, dan terhambatnya pertumbuhan pada anak, namun juga berdampak jangka panjang. Dampak jangka panjang yang ditimbulkan stunting adalah peningkatan risiko penyakit infeksi dan penyakit tidak menular di masa dewasa, serta penurunan produktivitas dan kemampuan ekonomi yang berdampak pada perekonomian global (Beal, Tumilowicz, Sutrisna, Izwardy, \& Neufeld, 2018).

Pertumbuhan balita yang optimal bukan hanya membutuhkan asupan gizi yang optimal dan pola asuh yang tepat namun mencakup tingkat pengetahuan ibu dan orang tua yang mempengaruhi pola asuh dan pemberian makanan pada anak. Praktik pemberian makan yang tidak tepat, seperti pemberian makanan prelakteal, menyusui non-eksklusif, pemberian susu formula, frekuensi makan yang rendah dan keragaman makanan, serta pemberian makanan pendamping ASI (MP-ASI) dini atau terlambat adalah faktor-faktor yang signifikan dapat menyebabkan stunting pada anak (Nurbaya, 2021a; Tariku et al., 2017). Karena penyebab stunting sangat kompleks dan saling terkait, maka perlu dilakukan berbagai upaya lintas sektor dalam upaya pencegahan stunting.

Berdasarkan penelitian yang dilakukan oleh Yunus dkk. tahun 2021 di Puskesmas Antang, Kota Makassar menunjukkan bahwa salah satu penyebab terhambatnya upaya penurunan stunting di masyarakat adalah rendahnya pengetahuan dan pemahaman ibu terhadap edukasi yang telah diberikan oleh pihak puskesmas (Yunus et al., 2021). Salah satu upaya yang dapat dilakukan untuk mengatasi masalah tersebut adalah melalui pemberdayaan kader Posyandu. Kader merupakan individu masyarakat yang memahami kesehatan dan posisinya sangat dekat dengan masyarakat sehingga memudahkan dalam memberikan informasi kesehatan. Kader posyandu merupakan perpanjangan tangan dari Puskesmas dalam rangka melaksanakan fungsi-fungsi kesehatan masyarakat. Kader Posyandu menjadi 
salah satu kelompok yang paling dekat dengan ibu balita di masyarakat. Kader posyandu menjadi salah satu sumber informasi langsung ibu balita sehingga berpotensi untuk meningkatkan pengetahuan ibu tentang kesehatan dan gizi termasuk pola asuh (Parmawati et al., 2020).

Bahkan, di masa pandemi Covid-19, kader tetap berupaya semaksimal mungkin untuk memberikan inovasi dalam pelayanan Posyandu agar tetap sesuai dengan protokol Kesehatan pencegahan Covid-19 (Najdah \& Nurbaya, 2021). Namun studi yang dilakukan oleh Vizeshfar dkk. menyebutkan bahwa rendahnya dukungan dan monitoring yang tidak memadai serta kemampuan komunikasi yang lemah pada kader Posyandu menjadi salah satu penyebab kurang maksimalnya kader dalam memberikan konseling dan penyuluhan (Vizeshfar, Momennasab, Yektatalab, \& Iman, 2021; Woldie et al., 2018)

Upaya peningkatan pengetahuan dan keterampilan kader Posyandu sangat penting dalam mendukung tugas-tugasnya sebagai kader (Woldie et al., 2018). Oleh karena itu, kegiatan pengabdian masyarakat ini bertujuan untuk meningkatkan pengetahuan dan keterampilan konseling kader posyandu dalam melakukan konseling gizi di masyarakat. Kegiatan merupakan salah satu bentuk kontribusi pada upaya kota Makassar mencegah terjadinya stunting pada balita. Upaya peningkatan pengetahuan dan keterampilan kader posyandu sangat penting untuk menciptakan kader yang berkompeten dalam mendeteksi potensi stunting pada balita secara dini.

\section{METODE}

Kegiatan pengabdian masyarakat ini merupakan hasil kerja sama antara Jalin Institute dan PKK Kota Makassar, Sulawesi Selatan. Kegiatan dilaksanakan di Puskesmas Panambungan Kota Makassar. Secara umum, kegiatan ini dilakukan dalam 3 tahap sebagaimana tergambar pada diagram alir berikut ini:

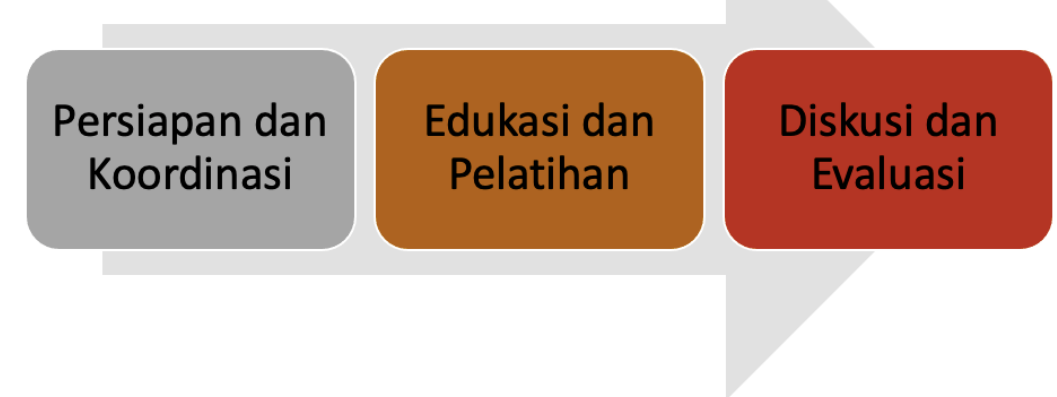

Gambar 1. Alur pelaksanaan kegiatan.

a. Tahap pertama yaitu tahap persiapan dan koordinasi. Pada tahap ini, tim melakukan koordinasi dengan Kepala Dinas Pengendalian Penduduk dan KB (DPPKB) Kota Makassar tentang tujuan pelaksanaan kegiatan dan pemilihan wilayah intervensi dan penentuan sasaran. Pada kegiatan ini diusulkan bahwa peserta merupakan kader perwakilan setiap Posyandu yang di wilayah kerja Puskesmas Panambungan. Kegiatan koordinasi dilakukan selama bulan Oktober-November 2021.

b. Tahap kedua yaitu tahap edukasi dan pelatihan. Sebanyak 33 kader Posyandu terlibat sebagai peserta. Kader diberikan edukasi dalam bentuk ceramah tentang stunting dan pemberian makanan pada bayi dan anak (PMBA) yang dibawakan oleh Icha Dian Nurcahyani, S.Gz. M.Kes. Materi kedua tentang dasar-dasar keterampilan dalam konseling yang dibawakan oleh Nurbaya, 
S,Gz. M.Gizi. Kegiatan ini dilaksanakan pada tanggal 22 November 2021

c. Tahap ketiga yaitu diskusi dan evaluasi dalam bentuk tanya jawab. Pada tahap diskusi, peserta diberikan kesempatan untuk bertanya tentang materi yang diberikan. Tahap evaluasi dilakukan dalam bentuk tanya jawab. Peserta diberikan pertanyaan terkait materi yang telah diberikan untuk mengetahui tingkat pemahaman peserta.

\section{HASIL DAN PEMBAHASAN}

Pada tahap persiapan dan koordinasi, disepakati bahwa Puskesmas Panambungan akan menjadi lokasi intervensi untuk pelaksanaan kegiatan pengabdian masyarakat ini. Dan sasaran utamanya adalah kader Posyandu yang berada di wilayah kerja puskesmas tersebut.

Puskesmas Panambungan dipilih sebagai lokasi pelaksanaan kegiatan karena Puskesmas Panambungan menjadi salah satu lokasi intervensi utama pada upaya percepatan penurunan kejadian stunting di kota Makassar. Oleh karena itu, sasaran utama pada kegiatan ini adalah kader Posyandu yang bekerja di wilayah kerja Puskesmas Panambungan. Sebanyak 30 kader Posyandu terlibat sebagai peserta dalam kegiatan ini.

Kegiatan pengabdian masyarakat ini diikuti oleh 30 kader posyandu yang merupakan perwakilan setiap Posyandu yang berada di wilayah kerja Puskesmas Panambungan. Mereka merupakan kader pilihan yang dinilai sebagai kader aktif yang dapat mentransfer pengetahuan yang diperoleh selama pelatihan. Kader memainkan peran penting dalam meningkatkan pelayanan kesehatan masyarakat dan menciptakan hubungan yang kuat antara masyarakat dan penyedia layanan sehingga dapat meningkatkan kesehatan masyarakat (Putra \& Yuliatni, 2016; Sari, Chiani, \& Astuti, 2020).

Tahap selanjutnya yaitu tahap edukasi dan pelatihan yang dilaksanakan selama 1 hari. Pada awal kegiatan dibuka oleh perwakilan Ketua PKK Kota Makassar, drg. Ita Anwar. Pada kesempatan ini drg. Ita Anwar menyatakan bahwa Pemerintah Kota Makassar berkomitmen menurunkan angka stunting hingga 5,5\% pada tahun 2021 2022 sehingga kegiatan pelatihan kader ini sangat penting dalam mendukung kegiatan pemerintah kota Makassar tersebut. Kegiatan ini juga dihadiri oleh Kepala Puskesmas Panambungan dr. Ela Saptaningsih. Kehadiran dan partisipasi para pengambil kebijakan sangat penting pada kegiatan ini sebagai wujud komitmen bersama dalam upaya penurunan stunting. Hal ini juga dapat mendorong pemerintah menyiapkan sistem dan manajemen intervensi yang lebih baik (Saputri, 2019). 


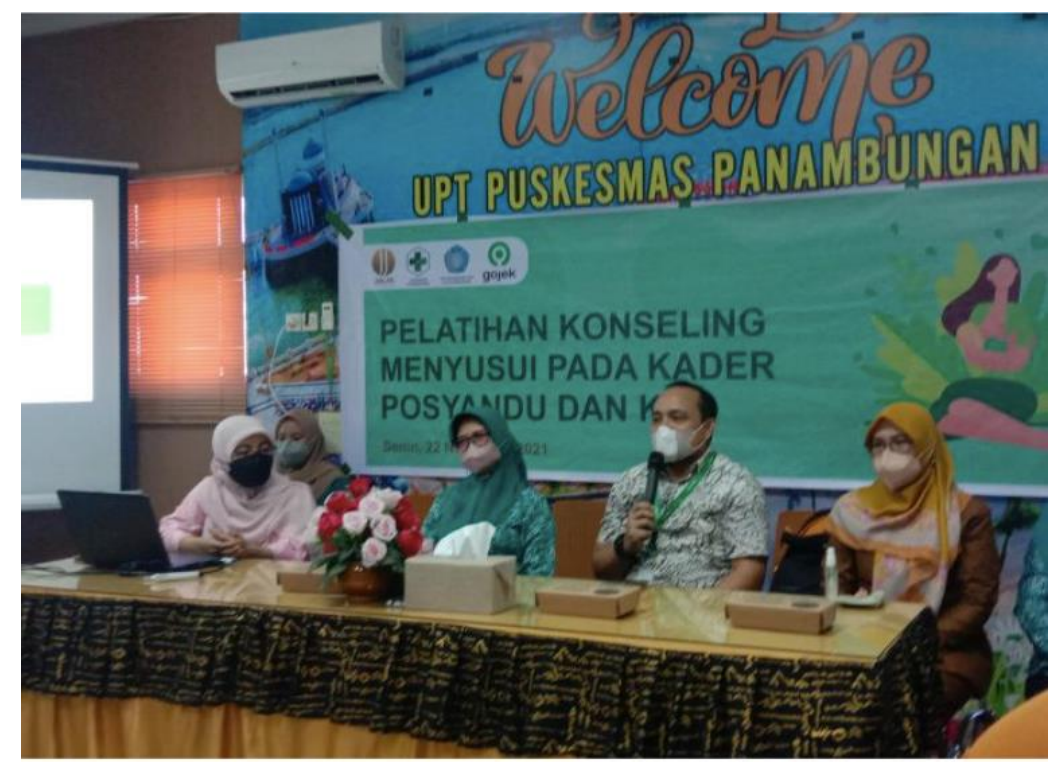

Gambar 2. Pemaparan tentang Program Pencegahan Stunting di Kota Makassar.

Selanjutnya adalah pemberian edukasi tentang stunting yang diberikan oleh Icha Dian Nurcahyani, S.Gz. M.Gizi, dosen Stikes Salewangan Maros. Materi yang diberikan antara lain tentang penyebab dan dampak stunting serta materi tentang PMBA termasuk tentang pentingnya ASI Eksklusif. Materi tentang stunting penting diberikan pada kader agar mereka lebih paham tentang penyebab stunting yang sering terjadi di sekitar mereka seperti rendahnya pemberian ASI, pola asuh yang tidak optimal, serta pemberian MP-ASI yang tidak tepat. Salah satu pertimbangan pemberian materi ini adalah berdasarkan riset yang dilakukan oleh Sari dkk. menunjukkan bahwa telah mempunyai pengetahuan yang baik tentang tugas dan fungsi Posyandu namun kurang masih rendah pada pengetahuan tentang gizi dan Kesehatan sehingga masih perlu diberikan pelatihan, bimbingan dan pendampingan (Sari et al., 2020).

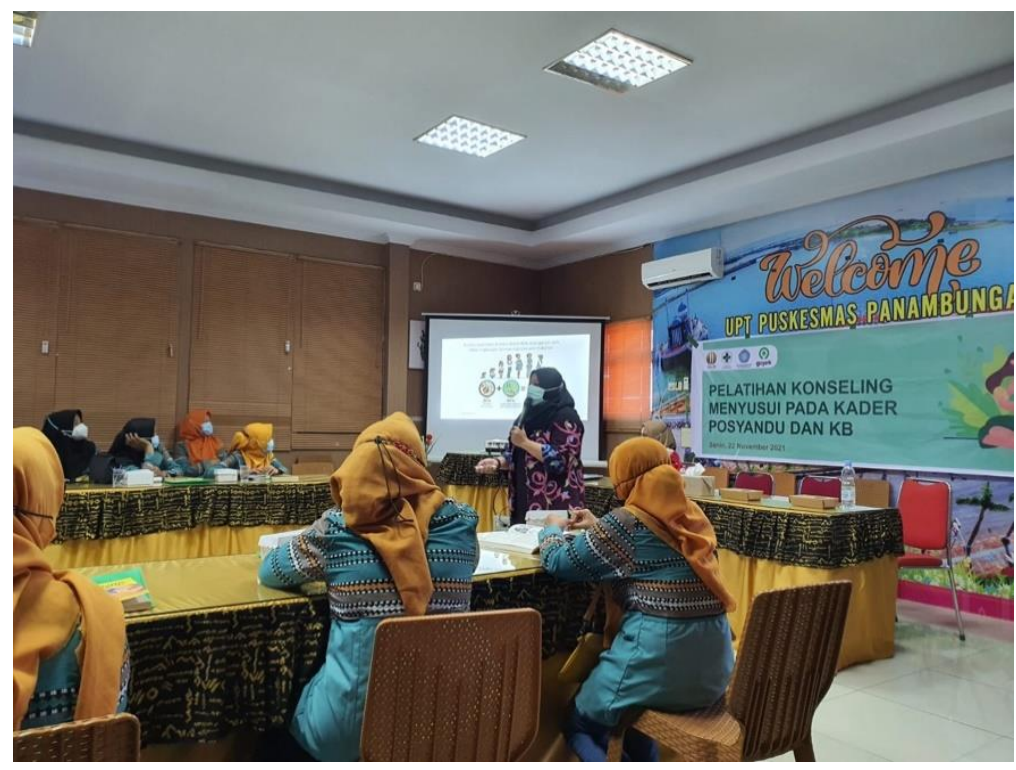

Gambar 3. Pemaparan materi tentang stunting.

Materi selanjutnya tentang keterampilan konseling yang dibawakan oleh Nurbaya, S.Gz. M.Gizi. dosen Jurusan Gizi Poltekkes Kemenkes Mamuju. Materi yang 
diberikan antara lain tentang etika dalam konseling seperti menjaga kerahasiaan klien, etika dalam berbicara serta keterampilan konseling lain yang penting antara lain keterampilan dalam mendengarkan dan memberikan umpan balik pada klien (Nurbaya, 2021b). Studi yang dilakukan Vizeshfar dkk. menyebutkan bahwa rendahnya kemampuan komunikasi dan konseling pada kader merupakan salah satu faktor penghambat kader melakukan konseling dan penyuluhan pada masyarakat (Vizeshfar et al., 2021). Keterampilan konseling tersebut sangat penting untuk terus dilatih setiap hari sehingga kader posyandu dapat memberikan konseling dan penyuluhan kepada ibu setiap saat ketika ibu membutuhkan informasi tentang gizi ibu dan anak. Setelah sesi pemberian edukasi, kader dilatih bagaimana melakukan konseling pada ibu baik di Posyandu atau di sekitar lingkungannya.

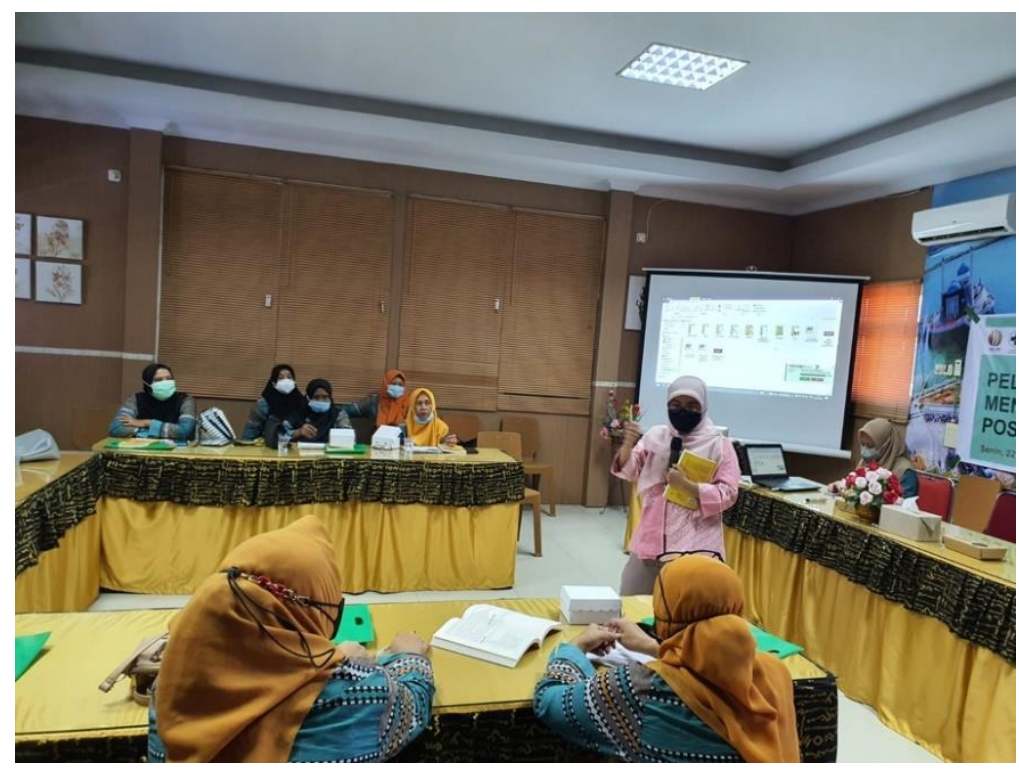

Gambar 4. Pemaparan materi tentang keterampilan konseling.

Metode yang digunakan selama kegiatan pemberian edukasi adalah ceramah. Hal ini karena beberapa penelitian menyebutkan bahwa metode ceramah dan diskusi memudahkan peserta memahami dan mempraktikkan materi yang disampaikan (Hapzah \& Nurbaya, 2021). Kegiatan diskusi dilakukan setelah pemberian edukasi. Kader diberi kesempatan untuk bertanya tentang hal-hal yang mereka kurang paham atau masalah yang mereka hadapi selama ini.

Selama masa diskusi, tim juga melakukan evaluasi dengan mengajukan pertanyaan kepada peserta terkait materi yang telah disampaikan. Sebagian besar peserta mampu memberikan umpan balik atau jawaban yang tepat dengan menggunakan bahasa sederhana. Beberapa peserta bahkan mampu menjelaskan tentang kekurangan mereka dalam melakukan konseling. Menurut peserta selama ini mereka kadang memberikan banyak informasi kepada ibu balita. Ada pula yang melakukan konseling dengan menggunakan bahasa yang sulit dipahami. Hal ini sebagaimana tergambar dalam pernyataan peserta berikut ini:

"Saya biasa memberikan banyak sekali informasi tentang stunting ke ibu-ibu. Padahal bisa jadi bukan itu masalahnya." (Kader)

"Kadang juga kita pakai bahasa-bahasa atau istilah-istilah yang susah dimengerti ibu. Padahal lebih dimengerti kalau kita pakai bahasa Makassar saja." (Kader) 
Setelah mendapatkan edukasi dan pelatihan ini, mereka menjadi lebih paham tentang etika dan keterampilan dalam konseling. Kegiatan diskusi secara langsung terbukti dapat meningkatkan pengetahuan kader. Bahkan pada penelitian yang dilakukan oleh Karuhadej dkk. yang memberikan pelatihan dengan metode diskusi terbukti cukup efektif dalam meningkatkan pengetahuan kader dalam kegiatan pelatihan (Karuhadej, Popijan, \& Danpradit, 2019). Berikut ini beberapa pernyataan peserta yang mendukung hasil evaluasi kami:

"Dulu saya pikir anak pendek itu tidak masalah. Yang penting sehat. Bisa main-main. Ternyata stunting ada dampaknya ke perkembangan otak." (Kader)

"Saya jadi tau kalau ternyata ada etika kalau melakukan konseling. Kita tidak boleh cerita masalah klien kita pada orang lain." (Kader)

"Saya jadi tau kalau ternyata daun kelor banyak kandungan gizinya dan bisa dibuat MP-ASI." (Kader)

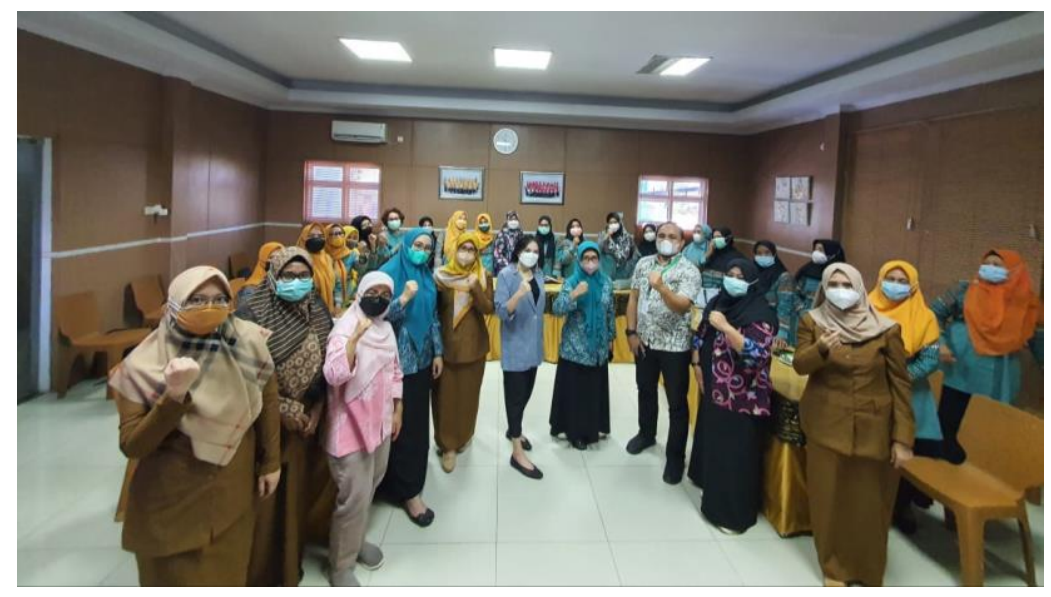

Gambar 5. Foto bersama Tim Pengabdian Masyarakat dan peserta

Kegiatan terakhir yaitu pernyataan komitmen bersama antara Tim PKK Kota Makassar, Puskesmas Panambungan dan kader Posyandu dalam upaya penurunan angka stunting di Kota Makassar. Kegiatan ini menjadi salah satu bentuk komitmen atas keberlanjutan kegiatan pengabdian masyarakat yang telah dilakukan. Komitmen pemerintah sangat penting dalam upaya pencegahan stunting (WHO/FAO, 2018).

Menurut Razak dkk., setidaknya komitmen pemerintah dapat dinilai dari tiga aspek yaitu, komitmen institusional, komitmen budget dan komitmen implementasi (Razak, Harpina, \& Adrianto, 2020). Dalam kegiatan ini, tim PKK dan Puskesmas Panambungan telah menampakkan komitmen institusional yaitu komitmen retoris yang diubah menjadi infrastruktur kebijakan termasuk institusi yang bertanggung jawab dalam mengkoordinasikan setiap kegiatan di masyarakat. Diharapkan, pihak terkait dapat menjalankan ketiga bentuk komitmen tersebut sehingga upaya penurunan stunting di Kota Makassar dalam dilaksanakan secara optimal.

\section{SIMPULAN DAN SARAN}

Kegiatan pengabdian masyarakat yang dilakukan dalam bentuk ceramah dan diskusi dapat meningkatkan pengetahuan kader Posyandu tentang stunting dan keterampilan dalam konseling. Selain itu, sebagai salah satu bentuk keberlanjutan kegiatan ini adalah komitmen bersama Tim PKK Kota Makassar, Puskesmas Panambungan dan kader Posyandu dalam upaya pencegahan stunting di Kota 
Makassar. Sebagai saran, perlu adanya pelatihan secara berkala yang diberikan kepada kader untuk persiapan mereka menjadi pendamping keluarga stunting yang akan diprogramkan oleh pemerintah Kota Makassar.

\section{UCAPAN TERIMA KASIH}

Terima kasih penulis sampaikan kepada seluruh kader Posyandu yang ada di Wilayah Kerja Puskesmas Panambungan, Kepala Puskesmas Panambunan dan staf, dan Tenaga Pelaksana Gizi (TPG) yang telah mendukung terlaksananya kegiatan ini. Terima kasih juga kepada Tim PKK Kota Makassar dan Gojek Indonesia yang telah mendukung dan mendanai pelaksanaan kegiatan pengabdian masyarakat ini sebagai salah satu wujud dukungan terhadap program pemerintah dalam penurunan angka stunting, terutama di Kota Makassar. Tidak ada konflik kepentingan (conflict of interest) pada kegiatan ini.

\section{DAFTAR PUSTAKA}

Beal, T., Tumilowicz, A., Sutrisna, A., Izwardy, D., \& Neufeld, L. M. (2018). A review of child stunting determinants in Indonesia. Maternal and Child Nutrition, 14(4), 1-10. https://doi.org/10.1111/mcn.12617

Hapzah, H., \& Nurbaya, N. (2021). Penyuluhan Metode Ceramah terhadap Pengetahuan lbu tentang Asupan Sayur dan Buah Anak SD. Jurnal Kesehatan Manarang, 7(1), 16-20. https://doi.org/10.33490/jkm.v7i1.232

Karuhadej, P., Popijan, M., \& Danpradit, P. (2019). Effectiveness of increase health volunteer ability program in basic care for the dependent elderly in the communities, Nakhon Pathom Province, Thailand. Journal of Health Research, 33(3), 219-227. https://doi.org/10.1108/JHR-08-2018-0068

Kementerian Kesehatan R.I. (2013). Riset Kesehatan Dasar (Riskesdas) 2013. Jakarta: Kementerian Kesehatan R.I. Retrieved from http://labdata.litbang.kemkes.go.id/ccount/click.php?id=1

Kementerian Kesehatan R.I. (2018). Hasil Utama Riset Kesehatan Dasar (Riskesdas) 2018. Jakarta: Kementerian Kesehatan R.I. Retrieved from http://labdata.litbang.kemkes.go.id/ccount/click.php?id=19

Kementerian Kesehatan R.I., \& BPS. (2019). Laporan Pelaksanaan Integrasi Susenas Maret 2019 dan SSGBI Tahun 2019. Retrieved from https://stunting.go.id/?smd_process_download=1\&download_id=5219

Najdah, N., \& Nurbaya, N. (2021). Inovasi Pelaksanaan Posyandu Selama Masa Pandemi Covid-19: Studi Kualitatif di Wilayah Kerja Puskesmas Campalagian. Jurnal Kesehatan Manarang, 7(Khusus), 67-76. https://doi.org/10.33490/jkm.v7iKhusus.548

Nurbaya. (2021a). Gambaran praktik pemberian makanan prelakteal pada bayi dan peran dukun anak di masyarakat adat Kaluppini. Jurnal IImiah Permas, 11(1), 41-50. Retrieved from https://journal.stikeskendal.ac.id/index.php/PSKM/article/view/904

Nurbaya. (2021b). Konseling Menyusui (1st ed.). Banda Aceh: Syiah Kuala University Press. Retrieved from https://ebooks.gramedia.com/id/buku/konseling-menyusui

Parmawati, I., Sandhi, A., Nisman, W. A., Lismidiati, W., Rustiyaningsih, A., \& Kholisa, I. L. (2020). Knowledge enhancement about pregnancy complications: Optimizing the role of high risk pregnancy prepared cadres. Journal of Community Empowerment for Health, 3(1), 18-27. https://doi.org/10.22146/jcoemph.47317

Putra, G., \& Yuliatni, P. (2016). Gambaran pengetahuan dan kinerja kader posyandu di wilayah kerja UPT Puskesmas Mengwi I Kabupaten Badung pada Bulan Juli-Agustus 2015. EJurnal Medika, 5(10), 1-9. Retrieved from https://ojs.unud.ac.id/index.php/eum/article/view/24119

Rana, R., \& Mavalankar, D. V. (2021). Effectiveness of Nutrition Interventions on World Health Organization Global Nutrition Targets: An Evidence Summary. Indian Journal of Community Medicine, 42(1), 147-150. https://doi.org/10.4103/ijcm.IJCM 
Razak, A., Harpina, S., \& Adrianto, R. (2020). Political Commitment of Local Government in Handling Stunting During the Covid-19 Pandemic: A Case Study of Enrekang District. Medico-Legal Update, 20(4), 2173-2181. https://doi.org/10.37506/mlu.v20i4.2168

Saputri, R. A. (2019). Upaya Pemerintah Daerah dalam Penanggulangan Stunting di Provinsi Kepulauan Bangka Belitung. Jurnal Dinamik Pemerintahan, 2(2), 152-168. https://doi.org/10.36341/jdp.v2i2.947

Sari, N., Chiani, S. H., \& Astuti, W. (2020). Tingkat Pengetahuan Kader Tentang Kegiatan Posyandu Di Posyandu Beringin Jaya Dusun Poto Tahun 2019. Jurnal Kesehatan Dan Sains, 3(2), 1-9. Retrieved from http://jurnal.lppmstikesghs.ac.id/index.php/jks/article/view/30

Tariku, A., Biks, G. A., Derso, T., Wassie, M. M., \& Abebe, S. M. (2017). Stunting and its determinant factors among children aged 6-59 months in Ethiopia. Italian Journal of Pediatrics, 43(1). https://doi.org/10.1186/s13052-017-0433-1

The Global Nutrition Report's Independent Expert Group. (2020). Global Nutrition Report. Retrieved from https://globalnutritionreport.org/reports/2020-global-nutrition-report/

Vizeshfar, F., Momennasab, M., Yektatalab, S., \& Iman, M. T. (2021). Empowering health volunteer's through participatory action research in a comprehensive healthcare center. BMC Public Health, 21(1), 1-9. https://doi.org/10.1186/s12889-021-10878-7

WHO/FAO. (2018). Driving commitment for nutrition within the UN Decade of Action on Nutrition: Policy Brief. Retrieved from https://www.who.int/publications/i/item/WHO-NMHNHD-17.11

Woldie, M., Feyissa, G. T., Admasu, B., Hassen, K., Mitchell, K., Mayhew, S., ... Balabanova, D. (2018). Community health volunteers could help improve access to and use of essential health services by communities in LMICs: An umbrella review. Health Policy and Planning, 33(10), 1128-1143. https://doi.org/10.1093/heapol/czy094

World Health Organization, \& UNICEF. (2021). Investing in our future: A comprehensive agenda for the health and well-being of children and adolescents. Geneva, Switzerland: World health organization (WHO). Retrieved from https://apps.who.int/iris/handle/10665/350239

Yunus, P., Septiyanti, \& Rahman. (2021). Analisis Implementasi Kebijakan Stunting di Puskesmas Antang Kota Makassar. Window of Public Heath Journal, 2(3), 1-10. Retrieved from https://www.jurnal.fkm.umi.ac.id/index.php/woph/article/view/479 